\title{
EMPLOYMENT-RELATED HIV TESTING - SOME CONSIDERATIONS
}

\author{
Elsabé Klinck \\ Legal Advisor, South African Medical Association
}

Medical practitioners can be either employers (when for example in private practice) or employees (when working for the state or another employer). They are also expected to deal with employers requesting HIV tests for prospective or existing employees. For these reasons they have to be familiar with the relevant provisions of labour law in this regard. The much-publicised cases of testing of domestic workers have emphasised instances where employers place doctors in difficult ethical and legal situations.

The Employment Equity Act of 1998 prohibits unfair discrimination against employees based on their HIV status. In the recent case of Hoffman v. South African Airways (2000 (11) BCLR 1235 (CC)) the South African Constitutional Court found the discrimination against an HIV-positive prospective employee to be unfair. The Court took notice of the employee's CD4 count, his actual ability to do the work and whether he would be able to take necessary medication for flights to African countries. The Court rejected arguments that passengers would feel uncomfortable with an HIV-positive flight attendant. It also rejected arguments that many other airlines have similar discriminatory policies, stating that discrimination elsewhere in the world cannot be used as a justification for unconstitutional behaviour in South Africa. Furthermore, this case means that refusal to retain an HIV-positive employee will be unlawful. Dismissal based on a person's HIV status constitutes a prima facie unfair dismissal in terms of the Labour Relations Act of 1995.

Section 7 of the Employment Equity Act prohibits the medical testing of employees and job applicants. This may only be done if the consent of the Labour Court has been obtained in this regard. The only case that has, up to now, dealt with this issue, reaffirmed the fact that testing at the request of an employer may only be conducted with the informed consent of each individual employee. This means that no employer may force an employee or job applicant to undergo an HIV test.

Confidentiality in relation to an HIV test and the results thereof applies even where the employer pays for the test. It is unlawful for a medical practitioner to test an employee solely at the request of the employer and to make the result known to the employer. If the employee provides informed consent that his or her status may be disclosed to the employer, the employer must keep that information confidential unless the employee consents to that information being made known to co-employees. These disclosures should take place with the necessary counselling and training exercises.

Do the same principles apply to doctors who are HIVpositive? The guidelines of the Medical and Dental Professions Board of the Health Professions Council of South Africa (HPCSA) on the Management of Patients with HIV infection or AIDS (July 2001) state that no doctor is obliged to disclose his or her HIV status to an employer or co-employee. Infected doctors may continue to practise, but have to seek counselling and advice so as to adjust their professional activities to protect their patients. In general, only scientifically justifiable restrictions will be permissible. Some aspects of medical training may be sensitive for HIV-positive medical students and doctors. Medical schools and facilities are currently attempting to address this issue so as to balance the rights of people to choose a profession with the rights of patients. The HPCSA has suggested that medical academic institutions should designate an appropriate and professional counselling service.

All employers should have HIV policies for the workplace and should conduct educational and training activities. Medical practitioners can play a constructive role in imparting scientific and clinical knowledge on this matter. The Code of Good Practice on HIV and AIDS in Employment, issued by the Department of Labour in 2001 (http:/www.labour.gov.za/docs/legislation/eea/index.asp), provides more details.

Employers who are not covered by the Employment Equity Act will be bound by the Promotion of Equality and Prevention of Unfair Discrimination Act of 2000. This Act also binds employers towards 'any person', i.e. not only employees, and claims may be lodged at any Magistrates' Court. South African National Defence Force members are not covered by most of the employment legislation. However, the Constitutional Court ruled in 1998 that they 
have a constitutional right to fair labour practices, which would include those in relation to HIV.

In terms of the Occupational Health and Safety Act of 1993 all employers have to adopt measures to reduce the risk of HIV transmission at work. These measures have to be rational and therefore based on the relevant scientific and legal facts. The Basic Conditions of Employment Act of 1997 stipulates the rights of employees to sick leave. HIVpositive employees may require reasonable accommodation in this regard and in the allocation of duties, etc. as prescribed by the Employment Equity Act.
Employees should also have access to medical aid schemes that must provide a minimum benefit to people living with HIV/AIDS. Although an employee does not have to disclose his or her HIV status to the medical aid, extra medical cover may be provided for in terms of special HIV programmes and it would benefit the patient to disclose that information to the fund. The patient/employee should disclose this fact rather than the medical practitioner to prevent legal action or complaints of breach of confidentiality.

\section{MEMBERSHIP}

\section{APPLICATION FORM}

CLINICIANS SOCIETY

MEMBER FEES FOR 2002

SA HIV Clinicians Society: Private Sector - R250 per annum and Public Sector - R125 per annum. These fees are now due.

NB PLEASE PRINT LEGIBLY AND RETURN TO:

The South African HIV Clinicians Society, Suite 233, PostNet Killarney, Private Bag X2600, Houghton, Johannesburg, 2041

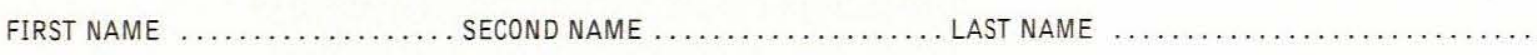

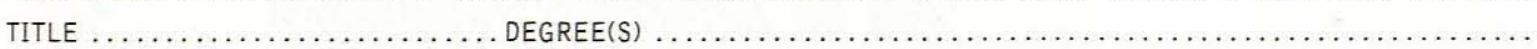

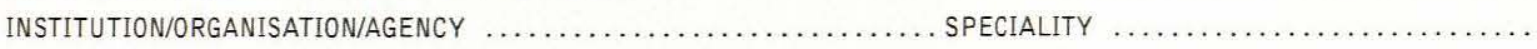

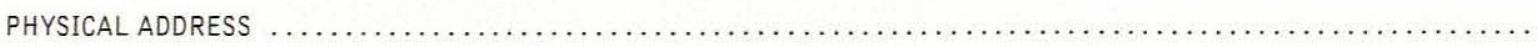

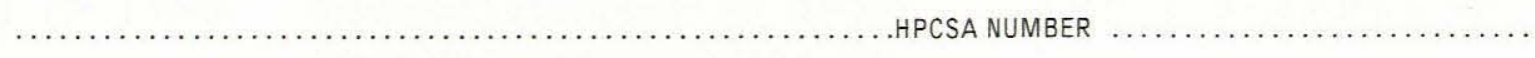

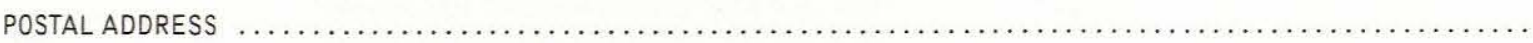

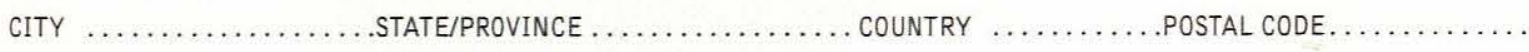

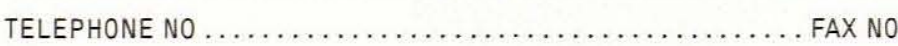

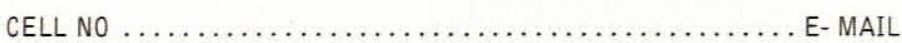

Please enroll me as a member of the SOUTH AFRICAN CLINICIANS SOCIETY

Please tick preferred Method of Payment $\square$ CHEQUE $\square$ DIRECT DEBIT $\square$ ELECTRONIC TRANSFER

IN FAVOUR OF THE SOUTH AFRICAN HIV CLINICIANS SOCIETY

Should you wish to deposit the membership fee, please ring (011) 4535066

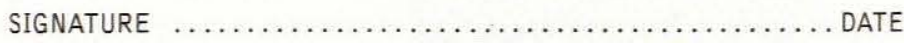

Do you practice in Southern Africa? $\square$ YES $\square$ NO $\square$ OTHER .............................................

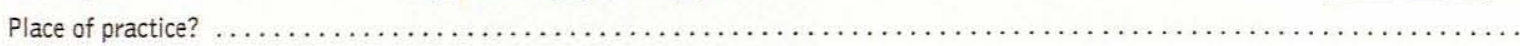

For how many years have you been treating HIV patients?

Is your area of HIV practice in: $\square$ PRIVATE SECTOR $\square$ PUBLIC SECTOR $\square$ BOTH PROPORTION: PRIVATE: PUBLIC:-:-

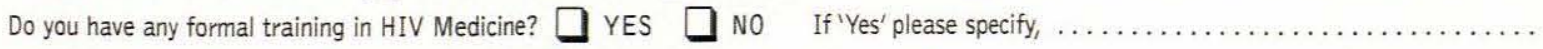
Approximately how many of your patients are currently receiving antiretroviral therapy?

Would you like to become a member of the HIV Clinicians Provider Network? $\square$ YES $\square$ NO

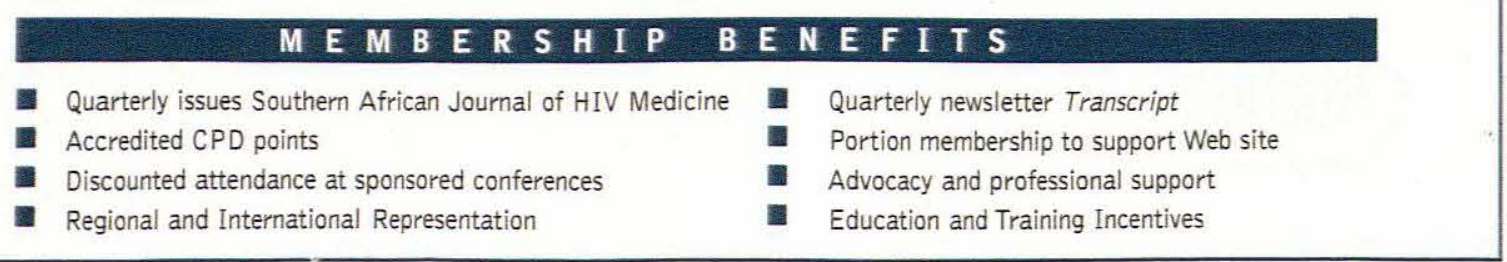

